\title{
Water Turbine Simulation using Autodesk Simulation CFD
}

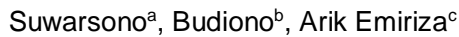 \\ ${ }^{a, b, c}$ Department of Mechanical Engineering, University of Muhammadiyah malang \\ Jl.Raya Tlogomas No.246 Telp.(0341) 464318-128 Fax.(0341) 460782 Malang 65144 \\ e-mail: suwarsono@umm.ac.id, budiono@umm.ac.id
}

\begin{abstract}
The need on electricity increases annually while its supply decreases, meanwhile power plant has not increased. Process of building microhydro power plant needs scientifically experience and more time to give suitable result as it designed. Sengkaling Cross-flow Microhydro power plant resulted inappropriate electricity power compare with designed power plant. The design is mostly not in accordance with planned calculation. It is caused by the engineer who is not considering surrounding condition. Therefore, simulation is very important to be conducted that it only needs short time to the design maximally arranged. By simulation, building and assembling process can be conducted faster and decreases error risks. Simulation for this research used AUTODESK SIMULATION CFD.
\end{abstract}

Keywords: Cross-Flow Turbine

\section{INTRODUCTION}

The need on electricity increases year after year, while government had no policy to build more power plant to supply electricity. Decreasing electricity consumption on State Power Plant (PLN), University of Muhammadiyah Malang built Microhydro Power Plant Sengkaling 1. Installed turbine used cross-flow system with water source from Brantas River/Sengkaling Dam. Water flowed to the left side of Sengkaling irrigation channel that is continuously gathered in the dam and flowed to penstock. When water reach $17 \mathrm{~m}$ of height in penstock, it results $3,88 \mathrm{~m}^{3} / \mathrm{s}$ debit and $500,310 \mathrm{~kW}$ water power.

Torque test to Sengkaling microhydro power plant was conducted with 2,10 m shaft of lever system and $55 \mathrm{~kg}$ of load that it resulted 139,633 kW of power. Result of torque test is $27,9 \%$ absorbed energy from resulted energy. It means that there is decrement on power resulted by this microhydro power plant. Accordingly, analysis is needed to estimate error caused power decrement through simulation and it can be conducted by using Autodesk Simulation CFD software.

\section{Methodology}

Problem discussed is very limited as depicted in the design based on data with 29 runner blades and $3 \mathrm{~m}^{3}$ debit. Meanwhile, analysis conducted by using Autodesk Simulation CFD software.

Water turbine or Water-sourced Power Plant is primary mechanism except generator. It changes potential energy of water to be mechanical energy, which furthermore, mechanical energy changes into electrical energy by generator. Water turbine was developed in $19^{\text {th }}$ century and was used widely for electrical power plant based on turbine principle in changing potential energy of water into kinetic energy. As the principle function of turbine, water falls to the blades push turbine to spin. Mostly water turbine is like windmill, it changes thrust function of wind to spin blades with water to move turbine. Turbine rotation is connected to generator. 
Cross-flow turbine is more beneficial than water mill or other kinds of microhydro turbine. The use of this turbine for the same power can save building cost for initial driving force to $50 \%$ of water mill usage with the same material. This saving can be reach because of smaller dimension of Cross-flow Turbine and more compact than water mill. Diameter of water mill, where it is spinning wheel or runner is mostly more than $2 \mathrm{~m}$ but in Cross-flow turbine it only needs $20 \mathrm{~cm}$ that less material is needed. It makes building cost is more inexpensive. Average efficiency of this turbine is higher than water mill. Figure 2.1 shows the components of regulator; they are (1) hand wheel, (2) threaded shaft, (3) threaded pads, (4) hinge, (5) bearing pas, and (6) intermediary lever.

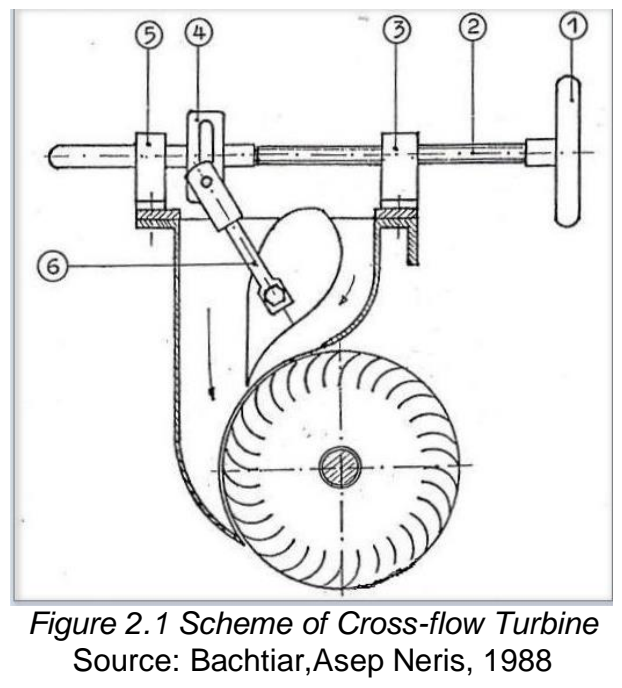

To operate Cross-flow turbine, firstly, open the main floodgate of the dam that water flow through channel to reservoir. When the water reach $1,5 \mathrm{~m}$ above penstock mouth that water partially wasted through surge tank because of it is in abundant, at that time penstock valve is opened to fill it with water. But, water cannot flow through turbine because inlet valve is fully closed. Furthermore, operational activity run in power house.

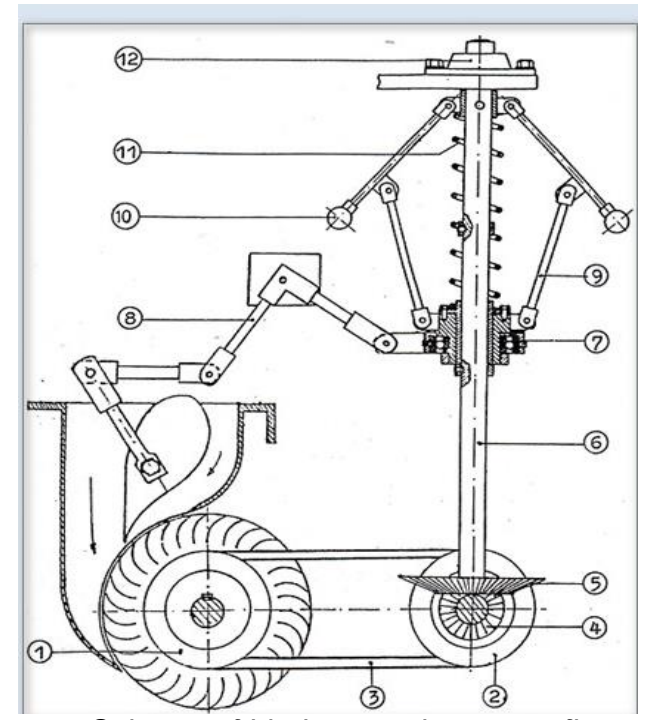

Figure 2.2 Scheme of blade control on cross flow turbine Source: Bachtiar,Asep Neris, 1988

Figure 2.2 shows governor components where (1) pulley on runner shaft, (2) pulley on intermediary shaft, (3) transmission belt, these three elements are components of 
power transmission system and rotation on runner shaft to governor shaft, (4) umbrella gear on intermediary shaft, (5) umbrella gear on governor shaft that it transmit power and rotation of intermediary shaft, (6) governor shaft is as railway of up and down and in this shaft the bearing located, (7) line bearing functioned as hook and lever carrier connected to valve, (8) levers functioned as movement connector of line bearing in valve position, (9) governor hands functioned as step continuer of line bearing and as determinant of pendulum position, (10) pendulum functioned to stabilize rotation and to obtain desirable step distance, it is very close to prevailed centrifugal, (11) spring, it gives reaction to line bearing that there is balance on action-reaction on operating system in mechanically automatic, (12) silent pad, it functioned to support the edge of governor shaft in steady that it can work in stable.

Inlet valve needs to be open periodically by using manual regulator that water can flow through nozzle and it spin the runner. When runner spin normally, release connecting peg between valve and regulator. Adjustment process of this valve is, furthermore, conducted by mechanical governor. During this initial operation, generator cannot be connected to load but after it works normally. Adjustment on power usage with automatic opening valve is conducted by governor.

In conducting simulation for cross-flow turbine, four steps were conducted. They are designing, determining material, boundary condition and initial condition. In designing, before simulation was conducted, turbine dimension should be determined and drafting process was conducted by using autodesk inventor. Afterward, in determining material, turbine was defined based on material installed on turbine. In boundary condition, input position was conducted with input/output flow. In initial condition, dysfunctional joint angles of turbine was determined during simulation that joint angles need to be lessen to conduct simulation.

\section{Result AND Discussion}

Based on mathematic calculation, obtained power resulted by turbine is $370.229 \mathrm{~kW}$, while water potential power can be calculated by using formulation and resulted 500,31 $\mathrm{kW}$. Efficiency of Sengkaling 1 Turbine according to mathematic calculation is 0,74 . From the result of torque test, power resulted is $139.633 \mathrm{KW}$, while power of potential water can be calculated with the result of $500,310 \mathrm{KW}$. It can be said that efficiency of Sengkaling 1 Turbine according to calculation is 0,28.

Result of simulation shows $275,005 \mathrm{~kW}$ of power, while water potential power can be calculated to obtain 500,310 kW power. Furthermore, Sengkaling 1 Turbine efficiency according to simulation is 0,55 . It occurs because of turbulence by water flow constrained by blade parser that water flow rotates as depicted in Figure 3.1.

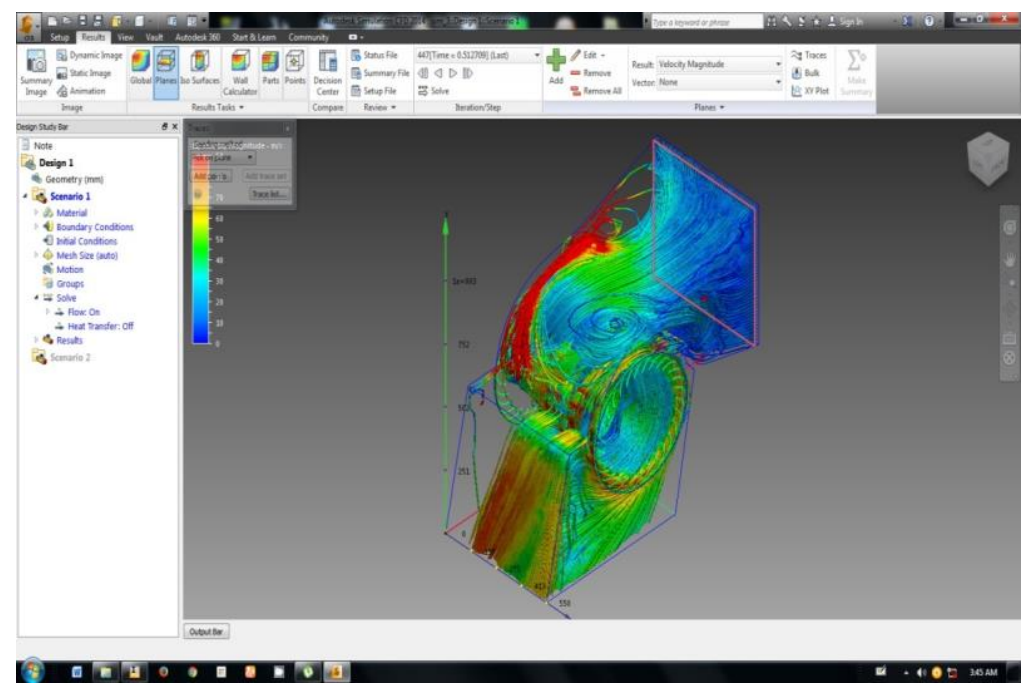

Figure 3.1 Result of T.S1 Simulation

JEMMME | Journal of Energy, Mechanical, Material, and Manufacturing Engineering 
Water potential power is energy owned by water to move or giving reaction. On the other hand, water potential is capability of water molecules to diffuse. On potential water, water moves from high to low.

$$
\mathrm{D}_{\text {air }}=\rho \cdot \mathrm{Q} \cdot \mathrm{H} \cdot \mathbf{g}
$$

Where:

$\rho \quad=$ Water density $\left(1000 \mathrm{~kg} / \mathrm{m}^{3}\right)$

$Q \quad=$ Water debit $\left(\mathrm{m}^{3} / \mathrm{s}\right)$

$\mathrm{H} \quad=$ Height of water fall $(\mathrm{m})$

g $=$ Gravity $\left(9,81 \mathrm{~m} / \mathrm{s}^{2}\right)$

Power resulted by water turbine can be written in mathematic equation as follow:

$$
D_{t}=g \cdot \eta_{t} \cdot Q \cdot H
$$

Where:

$$
\begin{array}{ll}
\mathrm{Q} & =\text { Water debit }\left(\mathrm{m}^{3} / \mathrm{s}\right) \\
\mathrm{H} & =\text { Height of water fall }(\mathrm{m}) \\
\mathrm{g} & =\text { Gravity }(9,81 \mathrm{~m} / \mathrm{s} 2) \\
\mathrm{\eta t} & =\text { Turbine efficiency }(\%)
\end{array}
$$

From the calculation above, debit is $3,88 \mathrm{~m}^{3} / \mathrm{s}$ because waterfly position is not recognized that debit is assumed $3 \mathrm{~m}^{3} / \mathrm{s}$ and head $17 \mathrm{~m}$ from the data give water potential power. Water power can be calculated with the formulation:

$$
\begin{aligned}
& D_{\text {air }}=\rho \cdot \mathrm{Q} \cdot \mathrm{H} \cdot \mathbf{g} \\
& D_{\text {air }}=1000 \cdot 3 \cdot 17 \cdot 9,81 \\
& D_{\text {air }}=500310 \mathrm{~J} / \mathrm{s}=500,310 \mathrm{~kW}
\end{aligned}
$$

Where:

$$
\begin{aligned}
\rho & =\text { Water density }\left(1000 \mathrm{~kg} / \mathrm{m}^{3}\right) \\
\mathrm{Q} & =\text { Water debit }\left(\mathrm{m}^{3} / \mathrm{s}\right) \\
\mathrm{H} & =\text { Height of water fall }(\mathrm{m}) \\
\mathbf{g} & =\text { Gravity }\left(9,81 \mathrm{~m} / \mathrm{s}^{2}\right)
\end{aligned}
$$

After observation, obtained data shows debit of $3 \mathrm{~m}^{3} / \mathrm{s}$, height of $17 \mathrm{~m}$ and efficiency 0,74 that turbine power can be calculated as follow:

$$
\begin{aligned}
\mathrm{Dt} & =\mathrm{g} \cdot \mathrm{\eta t} \cdot \mathrm{Q} \cdot \mathrm{H} \\
& =9,81 \cdot 0,74 \cdot 3 \cdot 17 \\
& =370229 \mathrm{~J} / \mathrm{s}=370 \cdot 229 \mathrm{kw}
\end{aligned}
$$

Where:

$$
\begin{array}{ll}
\mathrm{Q} & =\text { Water debit }\left(\mathrm{m}^{3} / \mathrm{s}\right) \\
\mathrm{H} & =\text { Height of water fall }(\mathrm{m}) \\
\mathrm{g} & =\text { Gravity }(9,81 \mathrm{~m} / \mathrm{s} 2) \\
\mathrm{\eta t} & =\text { Turbine efficiency }(\%)
\end{array}
$$

From the result of power calculation above, the resulted power of turbine is 370229 $\mathrm{J} / \mathrm{s}$ then turbine torque is:

$$
\begin{aligned}
\mathrm{T} & =\mathrm{F} \cdot \mathrm{r} \\
\mathrm{F} & =\mathrm{m} \cdot \mathrm{g} \\
& =\rho \cdot \mathrm{Q} \cdot \mathrm{g} \\
& =1000 \cdot 3 \cdot 9,81 \\
& =29430 \mathrm{~N}
\end{aligned}
$$

Accordingly, 


$$
\begin{aligned}
\mathrm{T} & =\mathrm{F} \cdot \mathrm{r} \\
& =29430 \cdot 0,6 \\
& =17658 \mathrm{Nm}
\end{aligned}
$$

From torque and power calculation, rotation can be calculated as follow:

$$
\begin{array}{ll}
\mathrm{Dt} & =(2 \cdot \pi \cdot \mathrm{T} \cdot \mathrm{n}) / 60 \\
370229 & =(2 \cdot 22 / 7 \cdot 17658 \cdot \mathrm{n}) / 60 \\
370229 & =(110993,142 \mathrm{n}) / 60 \\
\mathrm{n} & =22213740 / 110993,142 \\
\mathrm{n} & =2020,69 \mathrm{rpm}
\end{array}
$$

From calculation above, lost energy can be calculated mathematically as follow:

$$
\begin{aligned}
\text { Energy in } & =\text { Shaft energy }+ \text { lost energy } \\
500310 & =370229+\text { lost energy } \\
\text { Lost energy } & =500310-370229 \\
& =130081 \mathrm{~J} / \mathrm{s}=130,081
\end{aligned}
$$

Purpose of Prony brake turbine test is to know turbine torque and it is used to know the real power of turbine. Distance between bearing and pulley midpoint is $90 \mathrm{~cm}$ and total length of shaft is $210 \mathrm{~cm}$, while given load is $55 \mathrm{~kg}$. From the result of breaking Cross-flow turbine in microhydro power plant Sengkaling 1 , the obtained data is:

$$
\begin{aligned}
& \text { L.F1 = L2 . F2 } \\
& \text { 90.F }=210.550 \\
& \mathrm{~F} \quad=210.550 / 90 \\
& \mathrm{~F} \quad=1283,33 \mathrm{~N}
\end{aligned}
$$

Accordingly,

$$
\begin{aligned}
& T=F \cdot r \\
& T=1283,333 \cdot 0,6 \\
& T=769,9 \mathrm{Nm}
\end{aligned}
$$

Where:

$$
\begin{array}{ll}
\mathrm{F} & =\text { Power }(\mathrm{N}) \\
\mathrm{r} & =\text { Pulley radius }(\mathrm{m}) \\
\mathrm{L} & =\text { Length of bearing shaft }(\mathrm{cm})
\end{array}
$$

From the result of torque test, it is obtained that $769,999 \mathrm{Nm}$ of torque in $1731 \mathrm{rpm}$ rotation that power resulted by cross-flow turbine Sengkaling 1 can be calculated by using formulation as follow:

$$
\begin{aligned}
& \mathbf{D}_{\mathrm{t}}=\frac{T \cdot 2 \cdot \pi \cdot n}{60} \\
& \mathbf{D}_{\mathrm{t}}=\frac{769,999 \cdot 2 \cdot \frac{22}{7} \cdot 1731}{60} \\
& \mathbf{D}_{\mathrm{t}}=139633,818 \mathrm{~J} / \mathrm{s}=139,633818 \mathrm{kw}
\end{aligned}
$$

Where:

$\mathrm{T}=$ Torque $(\mathrm{N})$

$\mathrm{n} \quad=$ Turbine rotation $(\mathrm{rpm})$

From the calculation above, the lost power is calculated as follow:

$$
\begin{array}{ll}
\text { Energy in }_{\text {in }} & =\text { Energy }_{\text {shaft }}+\text { Energy lost } \\
500310 & =139633+\text { Energy lost } \\
\text { Energy lost } & =500310-139633 \\
& =360677 \mathrm{~J} / \mathrm{s}=360,677 \mathrm{KW}
\end{array}
$$


On the design of Sengkaling 1 Power plant, the number of blades capturing water flow from nozzle is 7 blades for 1 nozzle. According to Halmerl L.A 1960, the appropriate number of blades for 1 nozzle to capture water flow is 3 to 4 blades, while in the center of runner there is shaft constraining water thrust on blades when water left runner.

\section{CONCLUSion}

From the result of simulation on Sengkaling 1 Power Plant, energy lost occurred because of several factors; they are the more number of blades that water flow to runner constrained and caused turbulence. Besides, shaft in the center of runner constrains water thrust on blade when water left runner.

\section{REFERENCES}

[1] Gallen, S. (1990). Hydraulics Engineering Manual. Swiss: Swiss Center for Appropriate Technology.

[2] Mocxmore, C. A., \& Merryfield, F. (1949). The Bangki Water Turbin. Bulletin series, 6-27.

[3] Wiranto Arismunandar.(1982). PENGGERAK MULA TURBIN.Bandung : Intitun Teknologi Bandung

[4] DR. Artono Arismunandar,M.A.SC. \& DR. Susumu Kuwahara. (1982). Pembangkitan tenaga air. Jakarta : PT. PRADNYA PARAMITA 